\title{
Monitoring Analysis of Filling The Informed Consent of Blood Transfusion
}

\section{Ati Rusyda Ruhana1,2, Vivi Yosafianti Pohan², Tri Hartiti²}

1 Master of Nursing, Universitas Muhammadiyah Semarang, Indonesia

2 Universitas Muhammadiyah Semarang, Indonesia

\section{Article Info}

\section{Article History:}

Submit Jan 23rd, 2021

Accepted March 20th, 2021

Published March 28th 2021

\section{Keywords:}

Informed consent;

Monitoring; Documentation

\begin{abstract}
Informed consent is evidence of the accountability of health service providers in the hospital. it is carried out in every carrying out the procedure of actions that have the risk of causing disability or death. Incomplete documentation of patient informed consent can reduce the quality of hospital services. the implementation of informed consent documentation in hospitals often faces obstacles. this is due to the lack of human resources and the high workload available. This case study aims to determine the filling of informed consent documentation in the patient's blood transfusion. This study uses interviews, observation and document study by developing approaches to the nursing management function, organizing functions, personnel, direction, supervision, care management, logistics management, quality assurance programs and patient safety. The results showed that in one month there were 20 patients with blood transfusions, and 11 out of 20 patients did not have informed consent. The problem that arises is the incomplete documentation of medical records at the time of carrying out blood transfusions to patients. Supervision that is not optimal is the cause of this problem.
\end{abstract}

\section{INTRODUCTION}

Hospital is a health service unit of the health service system and is a strategic element seen from the context of the number of costs incurred, where most of the health funds are absorbed in the hospital management sector, both in developed and developing countries. Medical and care services are a subsystem of the existing service system in the hospital. The form of service provided is adjusted to the patient's condition so that it is more individual. ${ }^{1}$

Public demand for the quality of nursing services in hospitals is felt as a phenomenon that must be responded to by nurses. Therefore, this nursing service needs to be given top priority in future development. Nurses must be willing to develop their knowledge and change according to the demands of society and become professional nurses. Development in various aspects of nursing is interconnected, interdependent, influencing and having mutual interest. Therefore, innovations in nursing education, nursing practice, nursing science and professional life are the main focus of Indonesian nursing in the professional process. The professionalization process is a process of recognizing something that is

Corresponding author:

Ati Rusyda Ruhana

rusydaruhana@gmail.com

South East Asia Nursing Research, Vol 3 No 1, March 2021

ISSN:2685-032X

DOI: https://doi.org/10.26714/seanr.3.1.2021.40-44 
felt, assessed and accepted spontaneously by the community, so it is required to develop itself in the health service system. Because of the reasons above, nursing services must be managed professionally, therefore it is necessary to have Nursing Management. ${ }^{2}$

Management is a dynamic and proactive approach in carrying out an organizational activity. Meanwhile, nursing management is the process of working through members of the nursing staff to provide professional nursing care. The nursing management process is in line with the nursing process as a method of implementing nursing care professionally so that it is hoped that both of them will support each other. As happens in the nursing process, nursing management also consists of data collection, problem identification, planning, implementation and evaluation of results. Because nursing management is specific to the majority of an employee, each stage in the management process is more complicated than the nursing process. Nursing management must be applicable in real service settings in the hospital so that nurses need to understand how the concept and application are in the nursing organization itself. ${ }^{3}$

From the results of observations carried out for one week, starting from November 24 to December 1 , it was found that in 1 month there were 20 patients with blood transfusions, 9 patients had complete informed consent, while 11 patients had no informed consent. From the results of the interview with the Head of Team, it was found that, for information, the information had been given to the patient orally, but often forgot to write down the patient's medical record, because there were too many actions to be done while the nursing staff was limited. This can be seen from the records of the patient's status with the action of giving blood transfusions where there was no agreement sheet for giving blood transfusions as much as 55\%. From this, students concluded that the patient's completeness of informed consent was incomplete, this could reduce the quality of the hospital.

\section{METHODS}

This study has used a descriptive study design. The variable that has been researched in this case study is the documentation of informed consent by the nurse. The approach that has been used in this study is a case study.

The subject of this case study is a nurse who performs blood transfusion therapy for patients. The subject of this study was taken using the total sampling method. This study was conducted in the Baitussalam room of the Sultan Agung Islamic Hospital, Semarang.

Measurement of study variables that have been carried out are: observation, interviews, and study documentation. observations have been carried out on nurses who are carrying out blood transfusions to patients. interviews have been conducted directly to the nurse after completing the action. Documentation studies were carried out by looking at the patient's medical record documents.

All study subjects have expressed their consent and have signed a consent form to be the subject of this study. the researcher did not include the identity of the study subject. Researchers guarantee that the data that has been collected will not affect the work performance assessment of the subject of this study.

\section{RESULTS}

The results of the study have shown that there are 4 out of 8 implementation of the nursing management function. some of these problems include:

1. Informed consent for blood transfusion was not included in the patient's medical record. 
2. Supervision of the completeness of patient medical records is not optimal, especially in monitoring the completeness of blood transfusion informed consent documents.

3. The number of nurses is still limited

4. There are still many nurses who have a nursing diploma level.

Based on these problems, it can be concluded that the problem has been prioritized, namely: not optimal monitoring of the completeness of patient medical records.

researchers have formulated actions to solve these problems. action taken is to conduct socialization and re-education to nursing supervisors at the hospital.

This activity was carried out in December 2020. Socialization actions were carried out virtually through virtual meetings. This activity was attended by room leaders and team leaders for the Baitussalam room nurse, Sultan Agung Islamic Hospital, Semarang.

The results of the evaluation of the success of these actions indicated that there had been an increase in documentation of informed consent on blood transfusion actions by nurses by $25 \%$. This shows that it is necessary to re-educate the completeness of patient medical records, especially blood transfusion informed consent.

\section{DISCUSSION}

Based on the results of the study that was carried out in the Baitussalam 2 Room, there were problems in nursing management, that the evaluation of filling in informed consent in the provision of blood for transfusions was not optimal. informed consent is consent that is given to the patient on the actions to be carried out by doctors and nurses after getting a full description. The implementation of informed consent begins with the doctor planning what actions to give to the patient to what risks the patient will experience. From a legal point of view, documents that are not filled in completely will be weak as evidence, this was expressed by patient in Completeness of Filling Informed Consent Documents. ${ }^{4}$ This is as stated in the results of research by Sisca Adina Purnama, namely documents that are not filled in yet cannot fulfil legal aspects and are weak in physical evidence. ${ }^{5}$

Informed consent is also very much needed by patients because patients have the right in their medical information and actions to be taken against them so that it will support decision-making and can build a trusting relationship, this is in line with research conducted by Gong N. In Gong N's research, states that from the patient's point of view, informed consent that is not conveyed to them is an obstacle to decision making for actions to be carried out on them. ${ }^{6}$ In the research, N. Bowers revealed that a very good and regular explanation during the informed consent process can increase the patient's understanding of the procedure to be performed so that it will be beneficial to the patient and the procedure carried out will run well. ${ }^{7}$

Re-education on informed consent and form filling informed consent was implemented on December 10, 2020, through internet meeting, which was attended by 37 participants, and running smoothly. During the meeting, the participants were very enthusiastic. On 11 December in the conduct interviews with the staff back Baitussalam room 2 on informed consent that is the result: staff room Baitussalam 2 has been explained by either concerning the action of platelets along with the risks that would be received by the patient. After the interview with the staff, the students checked the patients who needed blood transfusions, with the results: the patient's family and the patient had understood well the explanation given by the nurse and had signed the informed consent form for giving blood for transfusions. In cases that are not 
well documented, it is because at the time of giving the education they are in the patient's ward, while the patient's medical records are in the nurse station so that the signing is often forgotten. In other cases, the family members described were different from the family members who were present at the time of the blood transfusion.

Yawi Sasmita Hasibuan's research on the factors that cause incompleteness of filling in informed consent in hospitals, namely: the knowledge of nurses about actions or procedures to be carried out on patients, nurses with good knowledge, so the informed consent is filled in completely ${ }^{8}$. In another study conducted by Susanto Primananda Dewangga et al, also mentioned that the factors affecting informed consent of patients are medical information that was conveyed to the patient is not complete, so that patients do not understand what is meant by good. ${ }^{9}$ Nurses play an important role in filling out the informed consent because the one who interacts most with patients is the nurse. For that, a nurse is required to have good knowledge of the procedures and actions that will be given to patients.

A nurse is required to be creative and innovative in taking action and providing education to patients. As did N. Bowers. In his journal, providing educational procedures to be carried out to patients in the form of multimedia, namely videos. In their research, it was found that $62 \%$ of all respondents understood better all procedures than those that were only explained orally. ${ }^{7}$ Barriers to completing informed consent are time, knowledge and coordination between management systems in hospitals or inpatient rooms, this was expressed by Sisca Adina Purnama and Sary in a Legal Perspective: Completeness of Filling in the Informed Consent Form in the Inpatient Room. ${ }^{5}$

PDSA implementation of monitoring completeness informed consent administer blood transfusions in Baitussalam Space 2, as follows:

1. Data analysis of monitoring implementation: Not optimal evaluation regarding informed consent for giving blood for transfusion

2. PDSA

Table 1

Planning of action

\begin{tabular}{|c|c|}
\hline Indicators & Detail \\
\hline Plan & $\begin{array}{ll}\text { a. } & \begin{array}{l}\text { Re-education on informed } \\
\text { consent }\end{array}\end{array}$ \\
\hline & $\begin{array}{l}\text { b. } \begin{array}{l}\text { Socialization back } \\
\text { charging informed consent }\end{array}\end{array}$ \\
\hline Do & $\begin{array}{l}\text { a. Implementation of seminars on } \\
\text { informed consent } \\
\text { b. Evaluation of filling in the } \\
\text { informed consent of } \\
\text { transfusion }\end{array}$ \\
\hline Study & $\begin{array}{l}\text { a. The staff has a good } \\
\text { understanding of informed } \\
\text { consent }\end{array}$ \\
\hline & $\begin{array}{l}\text { b. The staff understands the } \\
\text { importance of documenting } \\
\text { informed consent }\end{array}$ \\
\hline Action & $\begin{array}{l}\text { Evaluated the filling of informed } \\
\text { consent for giving blood in the } \\
\text { Baitussalam room } 2\end{array}$ \\
\hline
\end{tabular}

The problems that were found during the implementation of the nursing management application in the Baitussalam 2 Room apart from the inadequate evaluation of informed consent for giving blood for transfusions, namely: Lack of need for nursing personnel. Implementation: discuss with the head of the room to optimize the existing nursing staff. Evaluation: the existing nursing staff can be well optimized.

Conformity theory: good leadership and good communication will make staff feel more motivated and feel happy to make suggestions for service improvement. ${ }^{10}$

\section{CONCLUSION}

The management problem that arose in the Baitussalam Room RSI Sultan Agung Semarang was the incompleteness of 
documenting informed consent for giving transfused blood. The staff has explained it well and has been understood by the family and patient, but the documentation is still incomplete.

After re-educating the informed consent and filling in the informed consent form for giving blood for transfusions, the medical records of patients who need blood transfusions have been filled. From 55\% of patients' medical records, there was a significant increase, namely as many as $80 \%$ of patients who required complete blood transfusion. This is not apart from the monitor headspace in the completeness of informed consent administer blood transfusions. Apart from that, optimizing the nursing staff has gone well.

\section{ACKNOWLEDGMENTS}

The researchers would like to thank all those who have helped carry out this study.

\section{CONFLICTS OF INTEREST}

Neither of the authors has any conflicts of interest that would bias the findings presented here.

\section{REFERENCES}

1. Depkes. Standar Tenaga Keperawatan di Rumah Sakit. Edisi ke-1. RI DD, editor. Direktorat Pelayanan Medik; 2002.
2. Priharjo R. Praktek Keperawatan Profesional : Konsep Dasar dan Hukum. Jakarta: EGC; 2008.

3. Gillies D. Nursing Management: a System Approach. Philadhelpia: W.B. Saunders; 2004.

4. Samino S. Kelengkapan Pengisian Dokumen Informed Consent Di Provinsi Lampung 2013. J Dunia Kesmas. 2015;4(1).

5. Purnama SA, Sary L. Perspektif Hukum: Kelengkapan Pengisian Formulir Informed Consent Di Ruang Rawat Inap Bedah RSUD Menggala Kabupaten Tulang Bawang Provinsi Lampung Tahun 2014. J Dunia Kesmas. 2015;4(1).

6. Gong N, Zhou Y, Cheng Y, Chen X, Li X, Wang X, et al. Practice of informed consent in Guangdong, China: A qualitative study from the perspective of in-hospital patients. BMJ Open. 2018 Oct;8(10):20658.

7. Bowers N, Eisenberg N, Jaskolka J, Roche-Nagle G. Using a Multimedia Presentation to Improve Patient Understanding and Satisfaction With Informed Consent for Minimally Invasive Vascular Procedures: A Pilot Study. J Vasc Surg. 2013 May;57(5):59S-60S.

8. Hasibuan AS, Sasmita D. Faktor-Faktor Penyebab Ketidaklengkapan Pengisian Informed Consent Di Rumah Sakit Kesrem Binjai Tahun 2017. JIPKI. 2017;

9. Susanto DP, Pratama BS, Hariyanto T. Analisis Faktor -Faktor yang Mempengaruhi Pemahaman Pasien terhadap Informed Consent di Rumah Sakit. J Manaj Kesehat Indones. 2017 Aug;5(2):73-81.

10. Fatihah DC, Darmawanti N. Pengaruh Kepemimpinan Dan Komunikasi Terhadap Motivasi Serta Dampaknya Pada Kinerja Perawat Di RS AMN Subang PTPN VIII. J E-Bis. 2018 Jul;2(1):35-52. 